\title{
Escritura e narração: uma epistolografia da loucura e a emergência de um carteiro
}

Scripture and narration: an epistolography of the madness and the emergence of a postman

Escritura y narración: una epistolografía de la locura y el surgimiento de un cartero

Tiago Marcelo Trevizani

Rosane Azevedo Neves da Silva

Universidade Federal do Rio Grande do Sul (UFRGS), Porto Alegre, RS, Brasil

\begin{abstract}
Resumo
Este artigo apresenta parte de uma pesquisa realizada a partir do encontro com algumas cartas escritas por pacientes do antigo Hospício São Pedro (localizado em Porto Alegre/RS - Brasil). Trata-se de dezessete epístolas, datadas do início do século $\mathrm{XX}$, as quais não foram enviadas aos destinatários, pois ficaram anexadas aos prontuários. Este estudo busca refletir sobre a noção de escritura a partir dessa "epistolografia do hospício", dando visibilidade a algumas dessas cartas. Os autores apresentam a construção do personagem "carteiro", que se constituiu como um dispositivo metodológico para este trabalho. Ao longo do texto, realizou-se uma breve contextualização sobre a escrita epistolar, relacionando com a "escrita da loucura". Discute-se sobre a escritura como um modo de narração, partindo dos postulados de Roland Barthes e Walter Benjamin. Entende-se que as palavras podem ser uma forma de lidar com a dor e de testemunhar os horrores vividos na clausura.
\end{abstract}

Palavras-chave: Cartas do hospício. Escritura. Narração. Epistolografia.

\begin{abstract}
This article presents part of a research carried out from the meeting with some letters written by patients of the former Hospício São Pedro (located in Porto Alegre / RS - Brazil). These are seventeen epistles, dating from the early twentieth century, which were not sent to recipients because they were attached to their medical records. This study seeks to reflect on the notion of scripture from this "hospice epistolography", giving visibility to some of these letters. The authors present the construction of the character "postman", which was constituted as a methodological way for this work. Throughout the text, there was a brief contextualization about epistolary writing, relating to a "writing of madness". Scripture is discussed as a mode of narration, based on the postulates of Roland Barthes and Walter
\end{abstract}


Benjamin, understanding that words can be a way of dealing with pain and witnessing the horrors lived in the enclosure.

Keywords: Letters from the hospice. Scripture. Narration. Epistolography.

\section{Resumen}

Este artículo presenta parte de una investigación realizada a partir del encuentro con algunas cartas escritas por pacientes del antiguo Hospício São Pedro (ubicado en Porto Alegre / RS Brasil). Estas son diecisiete cartas de principios del siglo XX, que no fueron enviadas a los destinatarios porque se quedaron guardadas junto a los registros médicos. Este estudio busca reflexionar sobre la noción de escritura de esta "epistolografía de hospicio", dando visibilidad a algunas de estas cartas. Los autores presentan la construcción del personaje "cartero", que se constituyó como un dispositivo metodológico para este trabajo. A lo largo del texto, se realizó una breve contextualización sobre la escritura epistolar, relacionada con la "escritura de locura". La escritura es entendida como un modo de narración, basado en los postulados de Roland Barthes y Walter Benjamin. Las palabras pueden ser una forma de tratar el dolor y testimoniar los horrores vividos en la clausura.

Palabras clave: Cartas desde el hospicio. Escritura. Narración. Epistolografía

\section{Introdução}

Este artigo foi produzido a partir de uma pesquisa realizada com algumas correspondências escritas por pacientes do antigo Hospício São Pedro (localizado em Porto Alegre/RS - Brasil). A investigação partiu do encontro ao acaso com um conjunto de dezessete cartas, datadas entre os anos de 1909 e 1912, que ficaram arquivadas dentro dos prontuários médicos de alguns pacientes. Enquanto desenvolvíamos uma outra pesquisa com fontes primárias desse hospital psiquiátrico centenário, fomos surpreendidos pelo encontro com esses documentos que denominamos como "Cartas do Hospício"1.
Pierina e Isauro $^{2}$, durante a sua internação no Hospício São Pedro, escreveram cartas aos seus familiares, aos amigos e aos médicos assistentes, tratando sobre assuntos do cotidiano, pedindo notícias da família, solicitando que lhes trouxessem alguns pertences, suplicando que lhes tirassem daquele lugar.

Assim como muitas cartas de outros tantos autores que estiveram reclusos em asilos para alienados, as missivas escritas por Pierina e Isauro não chegaram aos seus destinatários, haja vista que ficaram anexadas aos seus prontuários, exceto, quem sabe, aquelas que eram enviadas aos médicos que talvez possam ter sido lidas por eles. 
Em um trabalho anterior sobre essa temática, escrevemos sobre as cartas como fontes de pesquisa e sua relação com a memória e o esquecimento (Trevizani \& Silva, 2019). Neste texto, pretendemos refletir sobre a noção de escritura a partir de uma "epistolografia do hospício", dando visibilidade a algumas dessas correspondências. Antes disso, porém, apresentamos a construção do personagem "carteiro", que se constituiu como um dispositivo metodológico da pesquisa.

Um carteiro tem como ofício levar uma mensagem adiante e o encontro ao acaso com as cartas do hospício fez nascer um carteiro. Nisto consiste este trabalho, fazer operar esse personagem que porta essas missivas que estavam esquecidas no arquivo. Este texto é, portanto, uma espécie de envelope para essas cartas que não foram enviadas.

Ao longo do artigo, fazemos uma breve contextualização sobre a escrita epistolar, relacionando com algumas outras pesquisas que abordam a escrita de cartas por sujeitos internados em hospícios. Discutimos sobre a escritura como um modo de narração, a partir dos postulados de Roland Barthes e Walter Benjamin, entendendo que as palavras podem ser uma forma de lidar com a dor e de testemunhar os horrores vividos na clausura.

\section{Sobre Cartas e Epistolografias}

Se o corriqueiro uso dos e-mails decretou a obsolescência das cartas, podese dizer que essa tecnologia de comunicação, ainda que considerada ultrapassada, guarda em si algum encantamento. Nas palavras de Galvão (2008, p. 15): “A disseminação do computador acabou com a carta e, na hora em que a matou, descobriram que era um objeto precioso".

Sejam escritas em papiro, ditadas aos amanuenses, ou perfumadas com fragrâncias apaixonadas, as cartas, enquanto gênero discursivo e literário, provocam certo fascínio e despertam interesses, por se tratar de um tipo de escritura muito peculiar. Em outras épocas, um pingo de cera quente lacrava as nobres correspondências e ganhava as formas do sinete ou o timbre do anel que imprimia as insígnias particulares do remetente; do mesmo modo, a pena, a tinta, a caneta, o mata-borrão, o envelope, o selo, o papel, a caixa dos correios são artefatos que compõem esse gênero textual. As cartas geralmente versam sobre os temas da vida, construindo personagens escreventes e destinatários, ao passo que articulam o objeto (a carta), o gesto da escrita e a escritura em um arranjo narrativo.

Costuma-se dizer que uma carta aproxima os ausentes; tais documentos 
funcionam em um "entre distâncias" (seja para diminuí-las, seja para aumentá-las). Ela constitui-se em um campo híbrido à medida que produz certa sociabilidade, ao mesmo tempo em que flerta com a intimidade, estabelecendo um território entre o público e o privado, colocando para funcionar as tramas da produção das subjetividades. Segundo Foucault (2004, p. 155) a correspondência: “[...] constitui também uma certa maneira de se manifestar para si mesmo e para os outros. A carta torna o escritor 'presente' para aquele a quem ele envia".

Uma carta instaura uma temporalidade e uma espacialidade, produzindo ressonâncias, encontros e partilhas, compondo uma história e uma geografia sempre inéditas. Uma correspondência agencia um conjunto de narrativas, não somente dos dramas a que se refere e dos enredos que registra, omite e fabula, mas também dos carimbos que recebeu, dos mecanismos de entrega e de extravio a que foi submetida, das paisagens por onde passou. Acumulam-se aos movimentos de partida e chegada o peso das digitais daqueles que a manusearam; os frisos milimetricamente dobrados e os vincos amassados acidentalmente; as rasuras, os borrões e os tremores de um titubeio da mão que a escreveu ou da língua que gaguejou; somam-se à superfície da carta as luzes e as sombras que ela habitou.

Se quiséssemos escrever "uma história das cartas", poderíamos lembrar que, pela notícia que temos, a escrita em língua portuguesa no Brasil foi inaugurada em uma carta. Pero Vaz de Caminha escreveu ao Rei de Portugal Dom Manuel, nos idos de 1500 na expedição que marcava a chegada dos europeus por estas paragens. Considerada por alguns como a "certidão de nascimento do Brasil", o texto do escrivão português relata com perplexidade os achados daquela jornada que adentrava, com olhar estrangeiro, a terra brasilis, à beira de sua colonização. "As cartas deram nascimento ao Brasil, serviram como elemento de mediação entre dois mundos: Brasil e Portugal cruzaram culturas, espaços e temporalidades distintos, cruzaram textos, produziram literatura" (Bettiol, 2008, p. 15).

As cartas costumam atender a uma série de regras de estruturação textual para o empenho retórico que lhe são próprias e que se instituem em cada época. A obra epistolar seiscentista do Padre Antônio Viera, por exemplo, obedece aos princípios prescritos pelo fundador da Companhia de Jesus, Inácio de Loyola, que, pela importância atribuída às cartas no projeto de expansão de sua Ordem religiosa, formulou uma metaepístola contendo 
regras sobre o modo adequado de escrever (Bettiol, 2008). No contexto de efervescência da contrarreforma católica, as correspondências do célebre jesuíta português expressam a sua ação missionária no Brasil colonial, assim como o seu legado político, literário e teológico.

O estabelecimento de padrões para a escrita das cartas passou a estar associado às regras de etiqueta e civilidade, de tal modo que no século XIX houve uma profusão de manuais com instruções para a produção de correspondências com elegância. Um clássico foi o "Código de Bom-Tom ou Regras da Civilidade e de Bem Viver no Século XIX", escrito pelo cônego J. I. Roquette, publicado em 1875. O livro dedica um capítulo exclusivo aos escritos epistolares, apresentando aquilo "que de modo nenhum pode ignorar uma pessoa bem criada" (1875, p. 209). Apresenta orientações quanto a uma boa caligrafia e rechaça veementemente os erros ortográficos e gramaticais, assim como qualquer tipo de rasura. Assevera ainda, sobre a escolha do papel:

Depois que o luxo inventou tantas especies e fórmas diversas de papel, não é indifferente a escolha d'este. Escrever em papel grosso, em meia folha, é só para os criados d'escada a baixo, e para o vulgo. Servir-se de papel dourado e perfumado para as cartas de negocio sería de uma vaidade ridicula. $O$ papel deve ser proporcionado às pessoas, idade, sexo, condição dos correspondentes. O papel dourado e perfumado [...] é destinado para as senhoras moças e para as pessoas cuja posição, habitos e dignidade supõem o luxo e a elegância. (Roquette, 1875, p. 210).

Os manuais dessa natureza colecionavam modelos de cartas para ocasiões e fins diversos e ofereciam sugestões de cabeçalhos requintados e despedidas eloquentes. De acordo com Vasconcelos (2008, p. 377):

\begin{abstract}
No Brasil, no século XIX e até meados do século XX, foram comuns esses florilégios como o Novo manual epistolar ou secretário de cartas particulares e Cartas de preditórios matrimoniais, com modelos de declaração de amor com o objetivo de honesto matrimônio. Sob o pseudônimo D. Juan do Botafogo, Figueiredo Pimentel publica, em 1897, о Manual do namorado, com o longo subtítulo "contendo a maneira de agradar às moças; fazer declarações de amor; vestir com elegância; estar à mesa; em bailes, em passeios e tudo quanto se usa na alta sociedade". [...] Incluem-se aí 100 cartas de namoro.
\end{abstract}

\section{Extrapolando os limites} pragmáticos da comunicação, encontramos, na história das cartas, algumas que assumem escancaradamente algo que, possivelmente, esteja presente em todas elas, a saber, a função literária. 
"Cartas Chilenas", de Tomás Antônio Gonzaga (1995), constitui-se como um belo exemplar de texto literário que faz essa operação estilística, no contexto da Literatura Brasileira, durante o período colonial. $\mathrm{O}$ autor, que assume o pseudônimo de Critilo, escreve ao seu amigo Doroteu (endereçando as cartas, na realidade, ao também escritor Cláudio Manoel da Costa) falando sobre os desmandos do Fanfarrão Minésio, o governador do Chile, que se mostra na narrativa como um verdadeiro déspota. Os versos, em tom satírico, parodiam a situação política de Vila Rica, em Minas Gerais, um pouco antes da Inconfidência Mineira, em 1789.

As cartas, enquanto gênero discursivo, são propensas a abordar o cotidiano e costumam reunir o disparate dos fragmentos heterogêneos da vida em certo arranjo narrativo. (Foucault, 2004). Mesmo aquelas trocadas entre intelectuais, escritores, artistas e outros personagens ilustres - as quais muitas vezes funcionam como verdadeiros laboratórios de suas obras, compartilhados com amigos e interlocutores - até mesmo essas, comumente, não escapam à tendência de narrar os minúsculos acontecimentos diários da vida dos remetentes.

No que se refere ao nosso campo analítico, que envolve a epistolografia e a "escrita da loucura", podemos constatar a existência de outros estudos que também se lançaram nessa empreitada. Encontramos o trabalho de Beverigde (1997) que analisou um conjunto de 1151 cartas escritas, entre os anos 1873 e 1908, por pacientes do Royal Edinburgh Asylum, na Escócia, as quais também foram mantidas nos prontuários. Lavín (2003) encontrou por acaso vinte e nove cartas escritas por pacientes da Casa de Orates, no Chile, nas primeiras décadas do século XX. Ríos (2004) localizou cartas e outros escritos pessoais que foram anexados aos prontuários de pacientes do Manicômio General La Castañeda, no México, a partir de 1900. Villassante, Vázquez de la Torre, Conseglieri e Huertas (2016) escreveram sobre as mais de cem cartas, redigidas entre 1900 e 1950, que ficaram anexadas aos prontuários do Manicômio Nacional de Santa Isabel en Leganés, na Espanha.

Além dessas pesquisas que tratam de cartas escritas por pacientes internados em hospícios de diferentes países, encontramos outros dois trabalhos que abordaram algumas epístolas redigidas por internos do Hospício São Pedro, ou seja, os estudos de Yonissa Wadi (2003) e a de Nádia Weber Santos (2005, 2008).

Wadi (2003), assim como nós, encontrou documentos de Pierina e remonta trechos da história dessa 
camponesa de 28 anos, casada, filha de imigrantes italianos de uma colônia de Garibaldi, que fora internada no Hospício São Pedro em 1909. A internação para fins de observação teve como motivo as perturbações mentais que a acometiam, as quais, conforme constatações da época, levaram-na a matar por afogamento sua filha de um ano e cinco meses em uma tina de lavar roupas. A pesquisadora investiga as interfaces entre a Medicina e o Direito, ao passo que reúne fragmentos biográficos da personagem, fazendo uma análise minuciosa do processo criminal que ela respondia; o prontuário do Hospício São Pedro; e as cartas de Pierina escritas no período de internação, entre 1909 e 1911.

Através da pesquisa desenvolvida por Santos $(2005,2008)$ tivemos acesso a um outro epistolário de um paciente internado, em 1937, no hospício da capital gaúcha. São as epístolas de TR ou de Ulysses Xavier do Rego (codinome que ele atribuiu para si em alguns dos seus textos). Pode-se dizer que as lidas na padaria e os negócios na fábrica de sabão da família eram para ele extremamente frustrantes. Escrever era uma das grandes paixões de TR, mas era também o motivo de intermináveis dramas familiares, uma vez que fora internado à revelia. Sua família dizia que "enfraqueceu da cabeça" devido ao fato de muito ler e escrever.
Nas suas epístolas, TR reúne citações de obras como Dom Quixote de La Mancha; menciona a psicanálise freudiana, o Apocalipse de S. João, passando por temas políticos, filosóficos e religiosos, dilatando a natureza autobiográfica das cartas ao arquivar elementos heterogêneos da sua história e dos tempos em que viveu. As cartas que escreveu durante os quatro meses que esteve internado eram endereçadas a personalidades ilustres, como o arcebispo metropolitano de Porto Alegre, D. João Becker; o escritor e jornalista Vianna Moog; o governador do Rio Grande do Sul, General Flores da Cunha; entre outros. Em uma das suas correspondências, escrita em alemão, ele faz de Adolf Hitler seu confessor, procurando purgar-se da culpa que carregava consigo de ter se "entregado sexualmente" a um padre na infância. TR compõe um mosaico em suas cartas, escrevendo a respeito de temas diversos. Falava seguidamente sobre um acontecimento que parecia lhe afligir: a Guerra Civil espanhola, a qual acompanhava atentamente pela leitura dos jornais, que a família levava para ele no hospício. Discutia sobre os regimes totalitários que eclodiam no mundo, manifestando ora apreço, ora desprezo pelas figuras de alguns ditadores. Sua antipatia pela Igreja Católica - da qual se 
declarava adversário - colocava-se lado a lado ao seu fervor religioso, assim como as suas incursões pela filosofia ${ }^{3}$. Ele narrava a experiência da escrita no hospício, apesar da escassez de papel e tinta: “[...] a todo instante sou interrompido por loucos que, ora me pedem cigarros, ora fogo, ora penna. Para dizer-vos basta que estou escrevendo encostado da latrina. [...] $\mathrm{E}$ negastes-me a tinta e o papel para “escrever" (TR, 1937 citado por Santos, 2008, p. 112; 122).

Durante o tempo em que pesquisamos nos prontuários, não localizamos as cartas de TR. Talvez eles tenham passado ao largo de nossa vista, considerando o imenso volume de papéis que constituem esse arquivo ou, quem sabe, não tenhamos chegado à caixa onde esses documentos hoje residem. A pesquisadora relata que seu encontro com esse epistolário também foi ao acaso; inclusive, ela informa que o seu prontuário estava arquivado em uma caixa de um ano diferente ao da sua internação, contrariando o sistema arquivístico do acervo. Além da escritura de TR, Santos (2005, 2008) analisa outros textos literários, com o intuito de utilizar a Literatura e a ficção como ferramentas para a problematização dos modos consagrados de escrita da História, provocando-a a se deixar contaminar pelo que chamou de "histórias das sensibilidades".

\section{Narração e Escritura: a fabricação de uma língua}

O hábito de escrever diários ocupava Lima Barreto, naqueles dias de 1919 e 1920, quando esteve internado no Hospício Nacional de Alienados, no Rio de Janeiro, "devido as suas bebedeiras". Observava e observava-se naquela "sombria cidade de lunáticos", registrando os delírios barulhentos e os silêncios emudecidos dos alienados com quem convivia. Ali, onde alguns se tornaram sombras e as grades interditavam os sonhos, Lima Barreto narrava as suas pequenas revoltas:

\footnotetext{
Estou entre mais de uma centena de homens, entre os quais passo como um ser estranho. Não será bem isso, pois vejo bem que são meus semelhantes. Eu passo e perpasso por eles como um ser vivente entre as sombras [...] Há os que deliram; há os que se concentram num mutismo absoluto [...] trepado e de pé na cumeeira, falando, cabelos revoltos, os braços levantados para o céu fumacento, esse pobre homem surgiu-me com a imagem da revolta... Contra quem? Contra os homens? Contra Deus? Não; contra todos, ou melhor, contra o Irremediável! (Barreto, 2010, p. 59, 67, 99).
} 
A experiência da internação em hospícios fora narrada através da escrita por alguns personagens que viveram nesses espaços asilares da loucura. Alguns desses textos foram publicados como é caso de "Diários do Hospício", de Lima Barreto. Existem, entretanto, outros tantos escritos que não tiveram a mesma sorte, ou seja, não atingiram o propósito que lhes fora previsto no momento da sua escrita, como as cartas do hospício que ficaram nos prontuários.

Publicados ou não, enviados ou não, esses textos em alguma medida narram algo da experiência no hospício. A narração é a arte de contar histórias, o que para Benjamin (1987) é indissociável da ideia de transmissão de uma experiência. De acordo com os textos escritos na década de 1930 ("Experiência e pobreza" e "O narrador"), o narrador tornou-se uma figura abalada, devido ao que Benjamin (1987) chamou de um declínio da experiência. $\mathrm{Na}$ concepção do autor, a modernidade deflagrou um empobrecimento da transmissão da experiência, devido aos modos de produção capitalista, promovendo um apagamento dos rastros do passado e vacilos na concepção da memória, evidenciando um menosprezo pela tradição e a uma fixação em um presente estéril de memórias.
Com Benjamin entendemos que modos de transmissão da experiência deslocam-se na história, oferecendo diferentes nuances para as possibilidades de compor as narrativas. As cartas fazem emergir algumas narrativas da loucura, apesar dos esforços de silenciamento a que foram submetidas. Quando propomos um trabalho com tais narrativas, não estamos apenas vislumbrando um mote para uma história da escrita da loucura, muito menos pretendemos realizar um deciframento da palavra do louco em termos psiquiátricos ou biográficos; mas, antes disso, estamos tomando-as como narrativas em tom de escritura.

A escritura é uma escrita que faz um uso muito peculiar da língua, pois subverte seu cânone e profana sua ortodoxia, fazendo-a variar. Para o escritor, no caso da escritura, "escrever é um verbo intransitivo". (Barthes, 2007, p. 33). O escritor não apenas desenvolve sua atividade como um "escrevente", no sentido de usar seu texto para comunicar algo, mas, ele escreve, somente escreve.

Leyla Perrone-Moisés (2002, p. 70) esclarece: "[...] para Barthes, é escritura ou texto todo discurso em que as palavras não são usadas como instrumentos, mas encenadas, teatralizadas como significantes. Toda escritura é portanto 
uma escrita, mas nem toda escrita é uma escritura".

A poética de Manoel de Barros expressa esse modo de lidar com a língua, operando um esgarçamento sintático e semântico: "Escrevo o idioleto manoelês archaico (Idioleto é o dialeto que os idiotas usam para falar com as paredes e com as moscas). Preciso de atrapalhar as significâncias [...] Não gosto de palavra acostumada". (Barros, 2010, p. 338; 348).

Em se tratando de Qorpo Santo, não são somente a sintaxe e a semântica que se tornam vertiginosas, mas a própria ortografia é reinventada. José Joaquim de Campos Leão, autodenominado Qorpo Santo, era assunto nas rodas de conversa da capital da Província de São Pedro, nos idos de 1860. Suas extravagâncias foram enquadradas pelo alienismo provinciano como "monomania". O dito diagnóstico motivou a internação dele no Hospício D. Pedro II, no Rio de Janeiro, e custou-lhe um processo judicial de interdição, haja vista seus "achaques de insanidade". Qorpo Santo escreveu inúmeros poemas e peças teatrais, sendo considerado um precursor do teatro do absurdo. Em 1877, decidiu abrir sua própria tipografia, para assim poder imprimir e publicar seus escritos (poemas, peças teatrais, textos jornalísticos, cartas e diversos outros gêneros textuais), reunidos nos nove volumes da sua "Ensiqlopédia ou Seis Mezes de Huma Enfermidade". Segue um fragmento do autor:

\begin{abstract}
Depois de 20 annos de huma vida sem manxa e de 12 de serviços no majisterio publiqo e patiqular, [...] qem qrerá qe depois de tantos frutos do trabalho inteleqtual, e material [...] qomeçaçe a ser injuriado, qaluniado, roubado inhabilitado moralmente para a jerencia de meus bens tão licitamente adqiridos: prezo, processado pelos proprios qrimes qontra minha pessoa e estes qometidos: obrigado a viajar esqoltado qomo hum qriminozo, ou algum desgraçado reqruta: metido em qazas de saúde, e em hospitaes qomo se sofresse alguma enfermidade (Qorpo Santo, 1877, p. 11)
\end{abstract}

Para esses autores, as palavras não satisfazem, é preciso fazê-las variar (Barthes, 2007) a escritura constitui, para eles, um tipo de literatura menor. "Uma literatura menor não é a de uma língua menor, mas antes a que uma minoria faz em uma língua maior" (Deleuze \& Guattari, 1977, p. 25). Trata-se de inventar um uso menor da língua maior: “eles minoram essa língua [...] eles fazem a língua fugir, fazem-na deslizar [...] e não param de desequilibrá-la, de fazê-la bifurcar e variar em cada um dos seus termos" (Deleuze \& Guattari, 1977, p. 124). 
Tais escritores, ao escrever, fabricam para si uma língua com uma estrangeridade sintática, semântica e ortográfica que desterritorializa a própria língua, fazendo-a delirar. Produzem uma metalinguística esquizo, maquínica e inventiva que opera através dos fluxos, não estando submetidas às ortodoxias linguísticas e não se reduzindo ao pragmatismo da lógica significantesignificado.

A intervenção que esses escritores fazem na língua e através da língua, provocando as suas arbitrariedades, suas ortodoxias e seus cânones, são, inequivocamente, intervenções estéticas e, ao mesmo tempo, são éticas e políticas. Segundo Deleuze (1992, p. 176), “é preciso que a linguagem não seja um sistema homogêneo, mas um desequilíbrio, sempre heterogêneo".

A despeito dessa heterogeneidade que é própria da linguagem, é sabido que não poupamos esforços para nos esquivar do engodo a que nos submetemos, de que a língua oferece-nos um lugar fiável no que se refere à significação, como algo plenamente partilhável no discurso. A palavra não serve para "explicar o mundo, ou pelo menos, quando ela finge explicá-lo é somente para aumentar sua ambiguidade" (Barthes, 2007, p. 33).
Partindo desse postulado, a tarefa de decifrar um texto, através da leitura que fazemos dele, seria perfeitamente prescindível, entendendo que os esforços de deciframento costumam estar ocupados em estabelecer "o que o autor quis dizer". Por essa ótica, não cabe ao autor a propriedade de um texto, nem mesmo a função de outorgar ao escrito o seu significado último, mas sim ao leitor que lhe atribui uma multiplicidade de sentidos que se engendram no ato da leitura. $\mathrm{O}$ "sentido de uma obra (ou dum texto) não pode fazer-se sozinho; o autor nunca produz mais do que presunções de sentido, formas, por assim dizer, e é o mundo que as preenche" (Barthes, 2007, p. 15).

Se para Barthes (2007, 2015) “escrever é um modo do Eros”, a leitura não é diferente disso, pois a dimensão do desejo ampara a relação do leitor com o texto. A respeito daquilo que chamou de "leitura desejante", o autor afirma: "na leitura todas as emoções do corpo estão presentes, misturadas, enroladas a fascinação, a vagância, a dor, a volúpia; a leitura produz um corpo transtornado [...] é com o corpo certamente que se lê" (Barthes, 2012, p. 38, 33).

Existem textos cuja leitura é interrompida frequentemente, pois pela sua pungência, pelo dilaceramento e comoção que nos causam, são lidos "levantando a 
cabeça", entrecortados por consecutivas interrupções. Tais interrupções são causadas "não pelo desinteresse, mas o contrário, por afluxo de idéias, excitações, associações [...]. É essa leitura, ao mesmo tempo irrespeitosa, pois que corta o texto, e apaixonada, pois que a ele volte e dele se nutre". (Barthes, 2012, p. 26). Podemos dizer que a ideia de trabalhar com as cartas do hospício foi disparada por um exercício de leitura, considerando "isso" que esses documentos nos provocam. $\mathrm{O}$ encontro com as cartas escritas em outros tempos nos desafiava a pensar "o que fazer diante desse encontro? ". O carteiro foi um personagem-dispositivo que tangencia o ficcional e assume uma função preponderante do ponto de vista metodológico.

\section{O Carteiro}

O ombro doía por causa do peso da bolsa, que naquele dia dava lugar a um pequeno maço de cartas - eram menos de vinte - mas que lhe pesavam de um modo extraordinário. Tirava e voltava a por o seu característico boné azul, enquanto coçava novamente a cabeça... Vertigens... Uma gota de suor escorria pela testa seguida por outras desertoras que brotavam incontroláveis, como uma resposta autônoma do sistema nervoso... Encontrar aquelas correspondências havia posto a sua função de carteiro em questão. Ele estava convencido: alguma coisa precisava ser feita...

O carteiro sentia-se responsável por sua descoberta. Estava disposto a mudar sua rota para atender ao imperativo que se colocara: acreditava que sua missão seria dar alguma resposta para aquilo que tinha a sua frente. Por um momento, pensou que sua tarefa seria restituir quem fora lesado pela brutalidade daquele procedimento institucional, que consistia no não-envio daquelas cartas.

Talvez, devesse vasculhar o arquivo de cabo a rabo para descobrir todas as cartas esquecidas entre aquelas centenas de caixas e naquele sem-fim de papéis. Para o carteiro não restava dúvida: as pessoas tinham o direito de saber que seus familiares e seus amigos que foram trancafiados em um hospital de alienados, tinham intenções de se corresponder com os que estavam além-muros, no entanto, eles foram privados disso. Os loucos do São Pedro queriam saber notícias, pedir umas miudezas, narrar seus dilemas, enfim, precisavam escrever para alguém, precisavam falar e serem escutados.

Um carteiro nunca lê as cartas que entrega, pois se as lesse, carregaria nas costas o peso das histórias do mundo. Agora, porém, não havia mais remédio, o olho do carteiro já havia cruzado as 
fronteiras da discrição, colocando-o diante daquilo que ele acreditava ser o seu fadado destino. As cartas lhe desacomodavam. Já não eram mais possíveis os caminhos usuais. Alguma coisa precisava ser feita...

$\mathrm{O}$ carteiro entendia que o encontro com aquelas cartas trazia-lhe à memória o perigo do esquecimento (Benjamin, 1987). Em seus pesadelos, contemplava com horror Mnemosyne, a deusa da memória, banhar-se descuidadamente nas águas do Lete, o rio do esquecimento, que corria pelos nefastos domínios do Hades (Weinrich, 2001).

O assombro do esquecimento amedrontava o carteiro, porque, se alguns "bailaram na curva", foram esquecidos, podia ele e todos os seus contemporâneos serem também esquecidos, condenados a desaparecer. Aliás, por falar nisso, custava ao carteiro disfarçar a sua implicância com essa história de que, hoje em dia, resolvese tudo por e-mail. Ele insistia que enviar cartas à moda antiga era de uma elegância, que uma mensagem eletrônica nunca estaria à altura. Evitava, no entanto, manifestar sua antipatia para não soar como despeito por ter seu trabalho preterido.

Ele tinha para si que seu ofício remontava à história dos arautos medievais que anunciavam solenemente para o povo os ditames do monarca, as notícias sobre a guerra e a paz. Não recordava se havia na sua estirpe antecessores ilustres. Pelo que soube, eram os escravos, os viajantes e os tropeiros que percorriam, em outras épocas, as distâncias levando as cartas e mensagens daqui para acolá. Ficava um pouco envaidecido pelo fato de que alguns que compartilhavam com ele o mesmo ganha-pão eram contados entre os santos lembrando o emissário celestial, o anjo Gabriel, comissionado para a anunciação das boas-novas à Virgem.

O carteiro é um sujeito que percorre distâncias. Enquanto caminha, tece becos e avenidas, sobe e desce ladeiras, inventa trajetos, descobre atalhos e se perde... Tudo isso, não sem se expor a alguns riscos. Seu corpo percorre o relevo das cidades, suas cavidades, suas curvas e reentrâncias, enquanto parte da sua geografia. Caminha buscando endereços (e endereçamentos) onde faz pequenas moradas provisórias e de onde se despede nesse seu obstinado caminhar.

Tal como um carteiro, nossa intenção com as cartas do hospício é levarmos a mensagem delas adiante, como um pesquisador-testemunha. Não recortamos do seu conteúdo determinados enunciados com fins de colocá-los em análise. Isso porque, se assim procedêssemos, muito facilmente poderíamos criar uma "hermenêutica das 
cartas" e cair nas armadilhas da interpretação e das explicações sobre as cartas ou sobre o que os autores quiseram dizer, em uma análise de conteúdo.

O pesquisador ao encontrar-se com esses documentos precisa estar atento para não se deixar levar pela sedução da representação que, nesse caso, pode ser entendida, ora como uma prerrogativa autoauferida de falar pelo outro ou no lugar do outro; ora como uma audácia interpretativa de estabelecer o que o outro quis dizer, ou criar uma teoria sobre o seu dito e o não dito. Spivak (2010) ajuda-nos a questionar o lugar do pesquisador, no que se refere a esse lugar da representação e à possibilidade de instauração de uma violência epistêmica, que torna o outro expropriado do direito à autorrepresentação.

A autora toma como ponto de partida para essa discussão o texto "Os intelectuais e o poder: uma conversa entre Michel Foucault e Gilles Deleuze" (Foucault, 1979) e problematiza alguns dos posicionamentos apresentados por eles nesse diálogo. Os filósofos criticam o pretensioso lugar do intelectual como "representante" de alguns grupos marginalizados (os prisioneiros, os loucos e, de um modo geral, daqueles que são tidos como "oprimidos"); questionam a intenção dos intelectuais de agirem na "tomada de consciência" do estado de exploração que esses grupos teriam em uma sociedade capitalista. $O$ que fica evidente aqui é a oposição às formulações da Teoria Crítica que estão presentes nesse modo de entender o trabalho do intelectual, preconizando o que poderíamos chamar de uma "superação" do marxismo.

O que Foucault e Deleuze afirmam, em suma, é que esses grupos não dependeriam das "boas intenções" dos intelectuais para constituírem seus saberes e, tampouco, para que possam falar por eles ou no lugar deles, pois, assumindo diferentes posições na dinâmica das relações de poder, tais grupos podem fazer isso por si. Spivak (2010), por sua vez, concorda com a assertiva da "indignidade de falar pelos outros" (Foucault, 1979, p. 72); no seu entender, o intelectual quando se julga capaz de "falar por representação" acumplicia-se com o sistema que oprime; quando tomado pelo acinte de "dar voz ao que fora silenciado", age em favor do silêncio e não ao contrário. Sua crítica, contudo, reside no fato de que tais autores desconsideraram as particularidades em que se encontram os sujeitos no/do Terceiro Mundo e, ao fazê-lo, repetem, mesmo sem querer, a atitude colonialista europeia; pois criam, não intencionalmente, a imagem equivocada de um "sujeito-universal" (apesar de 
criticarem a ideia de universalidade do sujeito), o qual seria capaz de se colocar em uma posição ativa no embate das relações de poder. Baseada nos estudos pós-coloniais, Spivak (2010) afirma que em determinados contextos de dominação, os efeitos do poder podem tomar proporções aniquiladoras do outro, marginalizando-os e destituindo-lhes o poder de falar. O subalterno pode falar (tem condições de fazê-lo e não precisaria de um representante), entretanto, as relações de dominação e assujeitamento em que se encontra interrompem as possibilidades do diálogo, de modo que, ao falarem, os sujeitos oprimidos não encontram meios de serem ouvidos.

Quanto às cartas do hospício, entendemos que são escritos potencialmente insurgentes, pois subvertem o silenciamento a que foram condenados aqueles que eram tidos como loucos. Contudo, esses textos foram capturados e impedidos de alcançar os destinos previstos por seus autores, ao passo que foram lançados nos prontuários. O contato com esses documentos nos permite encontrar com os efeitos de resistência daqueles que puderam testemunhar algo de suas vidas e do seu tempo, cabendo, portanto, ao trabalho com as cartas do hospício permitir que essas vozes sejam escutadas. A tarefa do pesquisador não consiste, portanto, em falar no lugar do subalterno, ele precisa criar meios para que, ao falarem, os grupos marginalizados, possam ser ouvidos; dessa forma, ele atende a sua vocação precípua, a de lutar contra a subalternidade.

Por causa disso, neste trabalho, optamos por transcrever algumas cartas, pela exiguidade de espaço não conseguimos apresentar todas elas. As transcrições respeitaram o modo de escrita dos autores, de maneira que foram evitadas, sempre que possível, as interferências no texto (exceto a substituição dos nomes por pseudônimos para a não-identificação dos autores, destinatários e demais pessoas citadas no texto, atendendo as prerrogativas da ética em pesquisa).

\section{As Cartas}

[?] de Outubro de 1909. Minha querida Mãe.

$\mathrm{Eu}$ vou, indo, muito, bem, bem tratada, e respeitada de todos e nem mereço mas sempre appenalizada, pensando, na minha triste sorte, mas, Deus, quis, assim, sejafeita, a sua vontade.

desejo saber noticias de toda, a minha, zente, mormente, da senhôra ê do meu marido.

Minha querida mandahime vossas noticias, e toda aminha roupa [?] que não 
presizo, e das cobertas, quero dois traberceiros bem seios, os meus cadernos, o livro, de missa, ou vosso retratto, aquelle, da minha amiga Luiza, aquelle do Senhor Eugenio [sobrenome] e dos meus compadres e também do meu marido, e das famillias dos irmanas, e irmãos se puderem, me mandar, Mandaime bastante palha branca e de cor [?] numero $1,3,5,7$, 9, que quero fazer treis ou quatro, tapetes mais que seja bem bonita;

Minha querida mãe muitas saudades de toda aminha zente, mas, ai em Garibaldi não desejo de voultar mais,

Meu, querido cunhado, falaes, com o Senhor Andréa [sobrenome] para mandar, a minha roupa in casa, do seu, irmão, Angelo, que elle venha ame, intregar, aqui, no, Hospício São Pedro, nas, minhas, mães,

Minha querida, mandaime, tudo, oque, vos, tenho pedido, por favor botaes, tudo, dentro, do meu, baul, mandahima, mais lizeiro que for posivel; muitas lembranças a toda, aminha zente, e tambem a todos, quem pedir, de mi:

Finalizo esta pequena carta mandando, lhe mil beijos, e um appertado abraço,

Sempre fico a sua affeituosa, filha Appenalizada, e amável
Ill.mos Srs.

João Luiz [sobrenome] e Jovin

Saudações

Desde o dia vinte oito de maio, proximo passado que estou visitando os pavilhões do Hospicio São Pedro! e os amigos, com toda certeza, tratando de suas conveniencias; muito bem, hoje em dia [?] em geral; mas meus bons amigos e ex collegas não devem ignorar de que quem faz a Deus paga ao diabo; devem saber também que não estou doido e nem tão pouco doente, e que sahi dos lares paternos com o fim de trabalhar, depois de minha penosa doença, que meu pae so em medicamentos gastou um conto e duzentos commigo, e com muito prazer; mas não terá nenhum prazer de gastar commigo um reis que seja numa caza como esta que so se trata de faculdades mentaes.

Bem, esta tem o fim de pedir aos amigos não que me venham retirar, porque talvez não tenham dinheiro; mas que ao menos venham aqui fallar com o tal doido e exporem suas razões; explicando por qual o motivo que se agarra um cidadão sem mais nem menos e conduze-se para uma casa de doidos. Pois meus bons amigos, eu apesar de doido, os convido para descutir sobre esse assumpto tanto pessoalmente, como pela imprensa e já quis publicar um artigo que a pedido do dr. 
José Carlos Ferreira não o publiquei. Eu doido mesmo como estou, faço lembrar aos amigos que no dia vinte oito maio pp. em [?] voltei da pharmacia Brasil onde fora pedir ao dr [sobrenome] um attestado afim de receber meus vencimentos durante os meses que estive doente, e que no Buffet, tomando uma taça de café disseram, digo disse Jovim: Sabe Isauro que estou fazendo annos hoje. queres dar um passeio de carro commigo? aceitei e viemos de carro toldo baixo até este arrabalde com o fim de visitar os pavilhões e voltar no mesmo dia e passear de automovel na rua da Praia, bom maneira de fazer o mais de bobo! Fazem a mim, porque eu costumo sempre a confiar-me em pessoas que não as conheço. Não sou um sujeito tão despresado como pensam talvez, e havemos de ver com o tempo, qual de nos somos doido. Se por ventura devo-lhes alguma cousa, telegraphem a [o nome do seu pai] basta, ou venham buscar a chave de minha mala que está no quarto $\mathrm{n}^{\circ} 19$ Hotel Savoia que encontrarão dentro da mesma: factos novos alguma joia de valor e duzentos mil reis em dinheiro que está as ordens dos bons amigos e ex collegas, ou talvez collegas.

Espero uma solução.

Isauro

HSPedro 9 de maio 1912.

\begin{abstract}
$* * *$
Illmo. Snr dr Dioclecio

Pereira

e mais membros da directoria

H. São Pedro

Saudações affectuosoas

$\mathrm{Eu}$ abaixo assignado natural d'este estado com vinte annos de idade, venho respeitosamente informar-me de V.as S.as porque motivo fui internado n'este Hospicio, pois como vossas idoneas pessoas não devem ignorar, eu não estive e nem estou doido e nem tão pouco doente, e se por infeliz sorte estivesse, ainda tenho a casa paterna.

Espero deferimento Isauro Porto Alegre 9 de junho de 1912
\end{abstract}

$$
* * *
$$

\section{A Dor e as Palavras - a Escritura como possibilidade de Insurgência \\ Com Barthes \\ (2012),} compreendemos os desencontros do ato comunicativo pelos impasses da significação, o que, para ele, confere um tom trágico às relações discursivas, como referíamos anteriormente. Por outro lado, entendemos que, por vezes, as palavras 
podem ser um modo de lidar com a tragédia, com a dor e o desespero. $\mathrm{Na}$ tentativa de dizer o indizível, lançando mão da palavra que rompe o silêncio, o imponderável das relações manicomiais. A escritura procura dar corpo a um testemunho.

Nesse campo que abarca a escritura e a loucura, Garavelo (2016) menciona que os usos das palavras não atestam a cura a quem quer que seja, mas funcionam como expansoras da vida onde ela se encontra aprisionada e silenciada pelos mecanismos de exclusão. "[As vidas] enxovalhadas pelas palavras de ordem e pelo silenciamento, manifestam-se em primeira voz, estendem a linha de fuga do esquadro que as aprisionou" (p. 162).

A relação entre a dor e as palavras permeia também as cartas do hospício. Pierina e Isauro, apesar das contingências, escrevem. Lançados nas garras da solidão, silenciados pelos mecanismos manicomiais, tiveram cada pequeno recanto de suas vidas inflamado pelo estigma da loucura. Contudo, eles se lançam na noite das palavras e escrevem, na expectativa a fazer aparecer alguns lampejos, na tentativa de fazer sobreviverem os vaga-lumes, em meio às trevas em que viviam. (Didi-Huberman, 2011). Nas palavras de Pierina:
Pacei tuda a noite escrevendo, tudo oque iscrevi aqui e todas verdade, como verdade que tem o sol e a lua. [...] Acabo porque estou com sono penso que isto sega aqui esta tudo esplicado. [...] agora não tenho mas nada no coração, Os Senhores me descurpes pellos erros, porque foi escrita, de toda noite.

As cartas de Isauro evidenciam a aflição de um jovem que saiu da casa dos pais, no interior do estado, para trabalhar em Porto Alegre e, num certo dia, se vê preso em um asilo de alienados, sem saber sequer as causas da internação. As epístolas e telegramas que escreveu durante esse tempo parecem atender à urgência de comunicar aos seus amigos e familiares aquilo que lhe ocorria naqueles dias tenebrosos de 1912. Ele formulava hipóteses sobre o porquê dois dos seus colegas de trabalho, João e Jovin, convidaram-lhe para um passeio de automóvel e acabaram o abandonando no São Pedro. Isauro suplicava que lhe tirassem daquele lugar, como pode ser percebido nas cartas transcritas.

As cartas de Isauro expressam a dor daquele moço cujas palavras foram, por determinado período, desconsideradas e seladas com os atributos da loucura. Ao mesmo tempo, suas palavras deslocam-se como uma possibilidade de insurgência, ao passo que ele empreende uma batalha com as formas de manifestação do saber-poder 
psiquiátrico, reivindicando a sua "sanidade".

Pierina e Isauro são testemunhas dos horrores vividos em um hospício, mas eles escrevem para afirmar a vida, para endereçar-se ao outro, para romper com as amarras que os modos de tratamento da loucura lhes impunham. A escrita é uma experiência que potencializa a vida, pois alarga os sentidos do mundo, podendo ser um "empreendimento de saúde". (Deleuze, 1997, p. 14). "Escreve-se sempre para dar a vida, para liberar a vida aí onde ela está aprisionada, para traçar linhas de fuga" (Deleuze, 1992, p. 176).

\section{Posta-Restante}

"Pos.ta-res.tan.te [s.f.]. Lugar onde ficam, no correio, cartas, pacotes, etc., até serem reclamados" (Ferreira, 2010).

Há certos textos cuja leitura desacomoda, inquieta e provoca. São textos que mobilizam o desejo de escrever (Barthes, 2012).

$\mathrm{O}$ encontro inesperado com as cartas do hospício instigou em nós esse desejo. O desejo de escrever sobre esses escritos que não alcançaram o seu destino e que não percorreram os caminhos previstos pelos seus remetentes. Fomos acometidos por uma vontade irrevogável de escrever sobre essas cartas que não encontraram descanso no regaço dos seus destinatários; que não testemunharam a alegria, as lágrimas, o contentamento, a vergonha ou o desprezo que poderiam ter produzido naqueles a quem se endereçavam. Antes disso, caíram na posta-restante; esquecidas no arquivo histórico, tais cartas ficaram à espera, à espreita de que alguém lhes reclamasse a existência.

Ao redigir uma missiva, o autor estabelece, inevitavelmente, uma relação com seu interlocutor, pois uma "carta prepara, de certa forma, um face a face". (Foucault, 2004, p. 156), ela instaura uma forma da presença de um para o outro. O escritor escolhe as palavras, antecipa as reações do seu leitor, antevê os efeitos do seu texto no momento em que for lido. Barthes (2012) afirma que um escritor, ao escrever, deseja o seu leitor; há um pedido de "ame-me" contido em toda a escritura.

Essa demanda de amor, subjacente nas cartas do hospício, é manifesta nos mais triviais pedidos e nos corriqueiros assuntos que são tratados. Nas epístolas, os autores solicitam algo aos seus destinatários, querem ser visitados, querem ser acolhidos; expressam seus anseios, seus temores, suas revoltas. Suplicam que os libertem da clausura que lhes foi impetrada. Há nessas cartas um murmúrio a ser escutado.

As cartas comovem porque são palavras que ficaram à deriva; palavras que 
ficaram soterradas entre escombros... Parafraseando a música de Chico Buarque (1993), as cartas são como as palavras de um amor não correspondido, palavras que ficaram guardadas num fundo de armário, esquecidas numa cidade submersa, à espera de que, talvez, algum dia, algum escafandrista as encontrasse.

As cartas falam em primeira voz e testemunham os horrores da clausura. As cartas provocam o imperativo do silêncio a que foram submetidos os seus autores, inaugurando uma possibilidade de insurgência. Elas saltam aos olhos no arquivo como um pequeno lampejo e ecoam como um grito dilacerante.

Apesar das contingências, Pierina e Isauro escrevem. Falam, apesar de serem contados entre aqueles a quem ninguém queria ouvir. Suas palavras procuram acender pequenas candeias na adensada noite em que viveram. A noite, entretanto, persiste...

A insistência da noite impõe a necessidade da lembrança e exorta quanto aos perigos do esquecimento. Lutar contra o esquecimento torna-se imprescindível, pois quando negligenciamos o passado, o presente é colocado em risco. Omitir-se perante a tarefa de elaboração do passado faz com que as mazelas históricas invadam o presente com sua força impetuosa, repetindo-se indiscriminadamente. Somos assombrados pelos fantasmas do passado e os tempos sombrios que estamos vivendo evidenciam isso. $\mathrm{O}$ recalcamento $\mathrm{da}$ memória e a denegação das nossas mazelas alimentam um obscurantismo perverso que relativiza o mal de forma vil e cruel. Nesse cenário, as estratégias de silenciamento se avolumam e a memória dos que sofreram as agruras de outros tempos é tripudiada. Lembrar-se do passado, neste caso, é intervir no presente; é fazer acender uma centelha de esperança. (Benjamin, 1987; Gagnebin, 2009).

$\mathrm{Na}$ abordagem que fizemos das cartas do hospício, evitamos as interpretações e as tentativas de estabelecer o que os autores quiseram dizer. Esquivamo-nos o máximo que pudemos da audácia de falar por ou no lugar daqueles que foram silenciados. Como um pesquisador-testemunha, ou como um carteiro, nossa intenção era levar essas mensagens adiante, como num revezamento (Gagnebin, 2009), fazer deste texto como um envelope para essas cartas.

\section{Referências}

Barreto, L. (2010). Diário do Hospício; Cemitério dos vivos. São Paulo: Cosac Naify.

Barros, M de. (2010). Poesia completa. São Paulo: Leya.

Barthes, R. (2007). Crítica e verdade. São Paulo: Editora Perspectiva. 
Barthes, R. (2015). O prazer do texto. São Paulo: Perspectiva.

Barthes, R. (2012). Barthes. O rumor da língua. São Paulo: Martins Fontes.

Benjamin, W. (1987). Magia e técnica, arte e política: ensaio sobre literatura e história da cultura (Obras escolhidas, Vol. 1). São Paulo: Brasiliense.

Bettiol, M. R. B. (2008). A escritura do intervalo: a poética epistolar de Antônio Vieira. São Leopoldo: Editora Unisinos.

Beveridge, A. (1997). Voices of the mad: patients' letters from the Royal Edinburgh Asylum, 1873-1908. Psychological Medicine, Cambridge University Press, 27. 899-908.

Buarque, C. (1993). Futuros amantes. In PARATODOS. Recuperado de https://www.youtube.com/watch?v =fuk4TNV0Nww\&list=RDfuk4TN $\underline{V 0 N w w \& s t a r t \_r a d i o}=1 \& \mathrm{t}=14$

Deleuze, G. (1992). Conversações. São Paulo: Ed. 34.

Deleuze, G. (1997). Crítica e clínica. São Paulo: Ed. 34.

Deleuze, G \& Guattari, F. (1977). Kafka: por uma literatura menor. Rio de Janeiro: Imago Editora.

Deleuze, G \& Guattari, F. (2011). $O$ antiÉdipo: capitalismo e esquizofrenia. São Paulo: Ed. 34.

Didi-Huberman, G. (2011). Sobrevivência dos vaga-lumes. Belo Horizonte: Editora UFMG.
Ferreira, A. B. de H. (2010). Aurélio: o dicionário da língua portuguesa. Curitiba: Positivo.

Foucault, M. (2004). A escrita de si. In M. Foucault. Ética, sexualidade, política (pp. 144 - 162). Rio de Janeiro: Forense Universitária. (Ditos e escritos V).

Foucault, M. (1979). Os intelectuais e o poder. In M. Foucault. Microfísica do poder (pp. 69 - 78). Rio de Janeiro: Edições Graal.

Gagnebin, J. M. (2009). Lembrar escrever esquecer. São Paulo: Ed.34.

Galvão, W. N. (2008). A margem da carta. Teresa: revista de literatura brasileira, 8/9(34), 14-29. Recuperado de http://www.revistas.usp.br/teresa/ar $\underline{\text { ticle/view/116656 }}$

Garavelo, L. M. C. (2016). Uma clínica da escrita: experimentações ateliais. Tese de Doutorado. Programa de Pós-Graduação em Psicologia Social e Institucional, Universidade Federal do Rio Grande do Sul UFRGS, Porto Alegre, RS.

Gonzaga, T. A. (1995). Cartas chilenas. São Paulo: Companhia das Letras.

Lavín, A. (2003). Cartas desde la Casa de Orates. Santiago de Chile: Ediciones de la Dirección de Bibliotecas, Archivos y Museos, Centro de Investigaciones Diego Barros Arana.

Perrone-Moisés, L. (2002). Com Roland Barthes. São Paulo: Editora WMF Martins Fontes.

Qorpo Santo, J. J de Q. L. (1877). Ensiqlopédia: ou seis mezes de huma enfermidade! Porto Alegre: 
Tipografia Qorpo Santo. (Volume 7: A saúde e a justiça). Recuperado de

http://biblioteca.pucrs.br/acervos/co lecoes-na-biblioteca/acervosespeciais/qorpo-santo/

Ríos, A. (2004). Locos letrados frente a la psiquiatría mexicana a inicios del siglo XX. Frenia, 4(2), 17-35. Recuperado de http://www.revistaaen.es/index.php /frenia/article/view/16408

Roquette, J.I. (1875). Codigo do bom tom ou régras da civilidade e de bem viver no XIX seculo. Paris: Livreiros de Suas Majestades o Imperador do Brazil e El-Rei de Portugal.

Santos, N. M. W. (2005). História de sensibilidades: espaços e narrativas da loucura em três tempos (Brasil, 1905/1920/1937). Tese de Doutorado. Programa de Pós-Graduação em História, Universidade Federal do Rio Grande do Sul - UFRGS, Porto Alegre,

RS.

Santos, N. M. W. (2008). Narrativas da loucura $e$ história de sensibilidades. Porto Alegre: Editora da UFRGS.

Spivak, G. (2010). Pode o subalterno falar? Belo Horizonte: Editora da UFMG.

Trevizani, T. M. \& Silva, R. A. N. da. (2019). Cartas do hospício: Memória e esquecimento - rastros e insurgências. Estudos e Pesquisas em Psicologia, 19(1), 313-336. Recuperado de http://pepsic.bvsalud.org/scielo.php ?script $=$ sci_arttext\&pid=S180842812019000100018\&lng=pt\&tlng $=\mathrm{pt}$
Vasconcelos, E. (2008). Intimidade das confidências. Teresa: revista de literatura brasileira, 8/9(34), 372 389). Recuperado de http://www.revistas.usp.br/teresa/ar ticle/view/116762

Villasante, O., Vázquez de la Torre, P., Conseglieri, A., \& Huertas, R. (2016). Letras retenidas: experiencias de internamiento en las cartas de los pacientes del Manicomio de Santa Isabel de Leganés, Madrid (1900-1950). Culturas Psi, (6), 118-137. Recuperado de http://ppct.caicyt.gov.ar/index.php/ culturaspsi/article/view/8328

Wadi, Y. M. (2003). A história de Pierina e as interpretações sobre processos de sofrimento, perturbação e loucura (RS/Brasil, século XX). Horizontes, Bragança Paulista, 21, 83-103. Recuperado de https://www.academia.edu/3696976 8/A_hist\%C3\%B3ria_de_Pierina_e _as_interpreta\%C3\%A7\%C3\%B5e s_sobre_processos_de_sofrimento_ perturba\%C3\%A7\%C3\%A3o_e_lo ucura_RS_Brasil_s\%C3\%A9culo_ XX_1?email_work_card=readinghistory

Weinrich, H. (2001). Lete: arte e crítica do esquecimento. Rio de Janeiro: Civilização Brasileira.

\section{Notas}

${ }^{1}$ Os documentos consultados fazem parte do acervo do Arquivo Público do Estado do Rio Grande do Sul (APERGS).

${ }^{2}$ Os nomes citados no texto são fictícios para que fosse preservada a identidade dos sujeitos da pesquisa. 
3 “'...] todo delírio é, primeiramente, investimento de um campo social, econômico, político, cultural, racial, pedagógico, religioso" (Deleuze \& Guattari, 2011, p. 362). O "inconsciente não delira sobre papai-mamãe, ele delira sobre as raças, as tribos, os continentes, a história e a geografia, sempre um campo social" (Deleuze, 1992, p. 180).
Tiago Marcelo Trevizani é psicólogo e doutor em Psicologia Social e Institucional pela UFRGS. Atua no Núcleo de Apoio Pedagógico (NAP) da Secretaria Municipal de Educação de Novo Hamburgo/RS (SMED/NH).

E-mail: tiagotrevizani@ hotmail.com

ORCID: http://orcid.org/0000-0003-00386663

Rosane Azevedo Neves da Silva é psicóloga e doutora em Educação pela UFRGS. Professora Titular do Instituto de Psicologia da UFRGS, participa da Linha de Pesquisa "Clínica, Subjetividade e Política" do Programa de Pós-Graduação em Psicologia Social e Institucional (PPGPSI).

E-mail: rosane.neves@ufrgs.br ORCID: http://orcid.org/0000-0001-6486$\underline{0630}$

Enviado em: 05/12/19- Aceito em: 22/09/20 